\title{
Democracy as Misunderstanding Between Freedom and Anarchy
}

\author{
Përparim Kabo \\ Associate Professor Doctor, \\ Dean, Faculty of Psychological, Social and Political Sciences, \\ Mediterranean University of Albania, \\ Gjergj Fishta Boulevard, Tirana 52, Albania
}

DOI: https://doi.org/10.36941/ajis-2022-0048

\begin{abstract}
The democracy issue is the keyword and concern of this paper. There have been long discussions about "democracy through law" and if it is a reality in Albanian society. The prolonged transition came because of a misunderstanding with democracy. Instead of checking and balance, power control is installed and the nearly antagonistic opposition between them. There is robbery and abuse of national assets, public property, and individual property, while the state legalizes informality. We face populism in the streets and populism in meetings organized in the halls. The mobs in the street are an expression of the ochlocracy and crowds at organized meetings. Anthropology of medieval society with crowds and modern "princes" is a story that follows in the last three decades in Albania. Democracy seems like a double monocracy and there is the killing of pluralism day by day. Governance with online portals and show-politics display as an illusion of functional democracy. Enhance the role of institutions and the attack against them, supposedly to protect the so-called interests of people in need. Democracy was wounded by a mass media that failed to return to either public power or independent power. Media in the hands of dubious owners. These are valuable topics of analysis and require the exchange of opinions to the benefit of the country on its road toward development. They are related to the immediate and prospective needs for profound changes in mentality, conduct, and democratic institutions. This study provides a historical and concrete analysis of the reality, brought together with the laws of democracy as a system, to reveal if institutional democracy is normally functioning in Albania. And if not, it intends to highlight. the reasons hindering it, as well as how this can be overcome, contributing to an educated society, that believes in freedom and builds a prosperous country.
\end{abstract}

Keywords: democracy, antagonistic opposition, captured institutionalism, authoritarianism, freedom, anarchy, populism, medieval society, functional democracy, mass media, orientalism, democracy as a culture

\section{Introduction}

Is the democratic system in Albania such as to convince one that Albanian society and anthropology have parted ways with the communist mentality? What about the feudal mentality? After all, have the ordinary man and the man engaged in the policymaking profession, emerged from the fog of Orientalism?

In order to give scientific answers to such questions, it is necessary to explain and convince people through arguments whether "Democracy through law" has been functioning in the last almost three decades in Albania. Are fundamental human rights and freedoms respected? Unfortunately, in 
the post-communist Albanian reality, "Freedom is considered as a game without rules, while anarchy as the freedom that can stand even above the law." The essential misunderstanding of democracy concerns freedom and anarchy.

The topic of this discussion is an open topic. From a life perspective, it is related to the immediate and prospective needs for profound changes in mentality, conduct, and democratic institutions. We need to understand that we have first to Europeanize our society, and then to integrate Albania into the European Union. Misunderstandings about democracy are such as to keep the individual in the "prison of history". To break away from them, does not merely mean to convert into the principles of democracy. To be educated with freedom is a challenge. According to Jean-Paul Sartre, "Consciousness has no inside...it is nothing but the refusal to be substance" (Domenach, 1984). In order to keep anarchy at bay, it is necessary to educate people with the principle of liberal democracy, "first order, and then freedom". Albanian society has still a long way to go...!

\section{Purpose of the Paper and Methodology}

\subsection{Research question}

Why institutional democracy does not function as a normalcy in Albania?

The answer that this research has set out to provide is because: "Democracy as a misunderstanding between freedom and anarchy." The anthropological mass of people that in the past history had not known institutional democracy is not versed in the culture of freedom. What democratic traditions can a people have in their culture and stands when for centuries they have experienced and only known authoritarianism, not democracy, as their political system? How much oriental culture does a society organized based on the structure of feudal anthropology and the scheme of the "mob and the chieftain" have inherent in it? Where the institutional culture is missing, it is replaced with the cult of possession and personalized institutions.

\subsection{The methodology used}

A historical and concrete analysis of the reality, juxtaposed with the laws of democracy as a system. This study contains a structured analysis of the fundamental elements determining the functioning of democracy as a system and its misuse in Albanian reality. Based on the behavior of ordinary man, the author is trying to draw up the anthropological profile of the crowd and the politicians or the high leaders of the state. The conclusions drawn as a result of a long, almost 20-year exploration of this matter, are set against the most important ideas of the authors who have written about Albania, in particular, and about democracy and the risks threatening it, in general.

\section{Findings and Discussion}

\subsection{Protracted transition as a result of a misunderstanding of democracy}

If the transition from one system to another requires a transitional period, this intermediary period is well understood since the past has not been fully relinquished and the future has not yet arrived fully, therefore from a mentality point of view, it is quite acceptable, but also from the aspect of the interests of the society, which needs time to gradually adjust to new developments.

The individuals or the social strata that lose their status and the security they enjoyed in their former favorable positions cannot easily adapt to the new circumstances or immediately acquire their social and economic status in the new system. Identification of that part of society that embraces change and makes sacrifices for it, beginning from cultural investments to understand what liberal democracy order is as a culture that transforms man from a nullity without freedom, to a free individual as an institution, would have ensured the broadest anthropological group and also the 
promoter to overcome the transition phase.

Failure to invest in this aspect explains why an overwhelming mass of people preserve the same conservative philosophy of behavior towards the state and its administration and institutions in general. The delay in changing people's mentality has also created a transitory situation in the spontaneous outlook of people, where the former historical vestiges mix up with the freedom of expression in a democracy. We hear people say: what is the government doing for me, where is the government, or the government should take care of us (a socialist mentality), or this is a government of robbers, a corrupt government (the understanding of freedom and state in the transition period). The common people say the same also in relation to parliament and the executive, the judiciary system, and the media power. There is simple arithmetic: "Are the institutions for the people, or against the people?" The stable constant may be formulated as such: "We the people wait to see what you politicians are going to do for us." There is community awareness whether: "The people who manage the affairs of the state and work in its different branches consider themselves "Public servants'; or are all-powerful and should somehow think also of the people and their concerns".

Have we as a society broken away from the philosophy of the communist slogan: "The party does what the people want, and the people do what the party says?" I am afraid that we have not yet broken away from it. The terms people and people's interests and needs are being misused. Currently, the government has opened an online portal for "Co-governance with the citizens" that it has named "The Albania we want". The opposition has for some time now boycotted the institutions, having identified with what it considers the power of the street people. It argues that "The people are dissatisfied, and we read it and in simony with it, we decide to leave parliament for good and give away also our mandates as deputies. In the two cases, the institutions and their independence are being attacked. With its online portal, the government is taking over and ignoring the powers and independence of institutions, giving them vertical orders after having collected the complaints of citizens. In this way, while the citizens are not being educated to hold accountable the institutions, kept with the taxpayers' money for not serving them, but are keeping alive the mentality of the old system whereby: "The great leader is in the service of the people; he is the only one that can solve our problems, indeed even by 'sacrificing' some minor officials". This is a kind of Machiavellianism in democracy. Balladur points out that "One of the duties of a politician is to stay close to the people he will lead. Gain their support and trust. Resemble them as much as possible". He further writes "Not all of them, of course - they are very different in their habits, interests, mentality - but most of them. For those for whom elections are more important, who represent the majority in polls, elections, comments?" (Balladur, 2007, p.54).

We have to do with a sort of state alchemy. The questions related to such an alleged online cogovernance which should be transformed into real concerns are the following:

- What is the contribution of the citizens to the governing aspect?

- What is the contribution of the citizens to the drafting of policies that protect the public interest?

- How can decision-making be drafted for the citizens to be proactive in governing?

- How does direct democracy function in tandem with complementary representative democracy, but also as a contribution to political decision-making?!

Without asking these questions, the discussion can't go further. If such questions are raised but no answers are given, then their answers do not exist, or there is a refusal to answer them. This explains why when electoral campaigns are organized, instead of hearing accounts rendered or guarantees given about a better functioning democracy, we hear promises made to build facilities or to provide services. Greenspan (2010) comments on such behavior in his book "The Age of Turbulence" saying "In all of its various forms, of course, economic populism stands in opposition to free-market capitalism. But this stance is fundamentally wrong and is based on a misconception of capitalism. The best evidence that populism is primarily an emotional response and not one based on ideas is that populism does not seem to recede in the face of repeated failure." (Greenspan, 2010, p.337).

Where democracy is treated as a material thing or as changed material conditions, then they 
pave the way to those who shall realize such things, and they are the private companies that flirt with the policymakers elected with the taxpayers' votes. Where public interest, is delegated to the private sectors in the form of concessions even in priority sectors like education, health, or public services, then it becomes clear that co-governance is de facto realized through the private sector, which is a real partner of the executive, the legislative, the media, and the judiciary system. Capitalism is buying and selling democracy in the market, while the public interest is beguiled with such forms that in essence are a departure from a real and functioning democracy. One of the anthropological concerns in the history of our people has been: "People should tend to their own problems, not to the public ones, which in fact embody also their own interests." (Fallmerayer, 1850$)^{1}$. Currently, such behavior is being fostered by this kind of manipulation, whose only novelty is the digital form of communication, a misleading form of appearance that hides a very outdated mentality.

Another aspect of the lacking democracy is that the same man in transition remains an eternal complainer, without developing into an individual that should take civic responsibilities and demand answers at least to these questions:

- Why does the government not function in all its tiers?

- Why do the institutions and the administration not properly serve the citizens?

- Why do institutions wait for vertical orders by the general staff of the political commander in chief?

Essentially, the opposition maintains the same stand. It shirks its institutional responsibilities. People are out in the streets as a discontented and angry crowd. Let us try to manipulate them as a stimulus for change, make them consider us, the opposition, as their savior. The treatment of the citizens not as free and law-abiding citizens, but as a protesting crowd that cannot be kept under control for what it seeks to achieve in the streets, in squares, or everywhere, is in essence a departure from democracy and a misunderstanding of freedom. There is no identified ratio between freedom and discontent. The discontented crowd is manipulated, and it does not target the situation but the institutions trying to block them or prevent them from functioning. The crowd becomes an indignant person that unwittingly stifles his own revolt.

"We protest; hence we are." The protest does not demand complete freedom. On the contrary, the protest is spearheaded against complete freedom. It opposes precisely the unlimited power that allows a superior official to trespass the allowed limit, said Albert Camus in his essay titled "The Rebel". (Camus, 2017) ${ }^{2}$. In their propaganda, they speak allegedly in the name of the people, and sometimes, in the name of all Albanians. The way they address their discontent is merely by venting their hatred against the government, by opposing change, and sometimes even by disobeying the actions based on the laws that restrict informality. It does not happen that discontent is translated into demands expanding democracy, freedom, and decision-making in favor of public interest

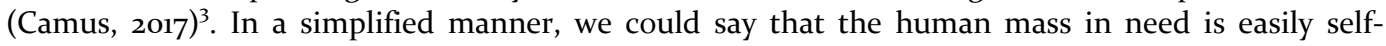

${ }^{1} J a c o b$ Philip Fallmerayer, in his book "History of Morea in the Middle Ages" published in 1850, would express himself so about the Albanians: "It seems that Albanians, besides the narrow-mindedness of their family and their clan, their personal gains and interests, their ire and revenge, have not felt the need to break out of such a world. Albania is the homeland of their shortsighted thoughts, the storehouse of their physical force, the place which they willingly refuse to obey to listen to themselves or to others. Albania is a constantly denying element and where anarchy and the absence of the rule of law to some extents are its soul and vital strength."

${ }^{2}$ Albert Camus, "The Rebel", "Starting from the spirit of revolt, it becomes aware that it is collective, an adventure of all ...The distress torturing a single man, becomes a collective plague. In our daily torment, revolt plays the role of 'cogito' in the order of thought; clarity comes first. However, such clarity brings the individuals out of their isolation. It is a joint reference that creates the first value for all people. I revolt, hence I am." Albanian edition, 2017, p.11

${ }^{3}$ Albert Camus, "The Rebel", "Revolt is not a demand for complete freedom. On the contrary, revolt rises against complete freedom. It precisely opposes the unlimited power which allows a superior to overstep the forbidden boundaries. Far from seeking general independence, the revolted man demands acceptance of the fact that freedom has its limits wherever a human being is involved and that such a limit is precisely the strength of this human being." 
manipulated, thinking that if those who are in power step down, and if people from their political wing come to power, they the discontented, who have taken to the streets, shall benefit; while the other part of the population lined up in support of the political force in power shall loose. The culture of cosmopolitanism is lacking, and for this reason, it is not yet understood that: "If we say democracy is valuable, then, roughly again, we want everyone to want to live in a democracy...There is no agreed-upon answer-and the point is there doesn't need to be. We can live together; we can agree about what to do in most cases, without agreeing about why it is right." (Appiah, 2006, p.21; p.71).

This kind of ritual has been kept recycling during the entire transition in Albania. Power has been separated from governing hence representative democracy is merely a partisan alignment. The principle "I am taxed, hence I am represented" does not apply at all. Instead of liberal democracy modifying the mentality and behavior of the individual, the opposite has occurred. Representative democracy has been mutated into the typical conduct and stand of the past system. It has given birth to a frightful hybrid which in essence is an expression of the typical conversion of Albanian anthropology into its historical course of development. Democracy has assumed the form of freedom to exercise authoritarianism from the top and of discontent that ends up in anarchic acts from the bottom. Politicians are on the side of the people for as long as they come to power, after that, the government is not there to serve the people, but solely to remain in power. Lipset (1959) makes a correlation between democracy and economy, evidencing that most countries that lack an enduring tradition of political democracy lie in the traditionally underdeveloped sections of the world. It goes in line with the suggestion of Max Weber that modern democracy in its clearest forms can only occur under the unique conditions of capitalist industrialization (Weber, 1906, p.346). Further on, according to Lipset (1959) "Some of the complications introduced by the sharp variations in political practices in different parts of the earth can be reduced by dealing with differences among countries within political culture areas."

As Soros has pointed out "This is the issue of representation, it is supposed that representatives uphold the interests of those they represent, but in fact, they tend to place their interests above the interests of those they are supposed to represent. The issue of representation is also the disease of representative democracy; elected representatives use their power in their own interests, to the detriment of public interest." (Soros, 2010). The Nobelist Joseph Stiglitz elaborates this issue as well in his book "Ethics, Market and Government Failure, and Globalization" (Stiglitz, 2012)

It is more than two decades that elections in Albania are no longer a choice or an indicator of sound democracy, nor do they have anything to do with the expansion of freedom and reliable functional institutionalism. Representative democracy does not function either as delegated sovereignty or as a responsibility to the sovereign. Finally, we heard the opposition leader Mr. Lulëzim Basha visioning his opinion at a meeting with some discontented people, repeating an expression that has gone down in history as a slogan "Everything for the people, with the people and nothing against the people," said by Hungarian Lajos Kossuth almost 170 years ago. This expression was used also by Abraham Lincoln, who credited it to Lajos. I have only one question for Mr. Lulzim Basha. "You were in power several times and for long spells, why did you not apply this principle? If you did not know of it, it would be a grave mistake, if you did know it and did not apply it, it would be an unpardonable mistake." The sovereignty of the people cannot be the next lie and a justification to come to power.

\footnotetext{
${ }^{4}$ Nobelist Joseph Stiglitz in the introduction of his book "Ethics, Market and Government Failure, and Globalization", says that "industrialized countries have given globalization a structure that infringes some of the basic principles of ethics."..., while in another place, while analyzing this argument, he says, "extreme egotism runs against ethical interests "and underlines that, "It is the moral responsibility of everyone to think about the consequences of their actions on the others, including the poor, and the impossibility to do this is an ethical weakness." Reference taken from the Italian version of the book, titled: LA BUSSOLA IMPRECISA-L'etica Nel Mondo Della Finanza Globalizzata, pp. 5,9
} 
The long Albanian transition is in essence an expression of the missing culture of representative democracy conditioned by the extreme economic polarization, but it is also an outcome of the failure of the individual to exercise his/her rights of liberal democracy. According to the latest statistics of the World Bank (2021), Albania is ranked as the poorest country in the region. The WB reports that the upper middle-income poverty rate (\$5.5) for Albania in 2020 is 33.8 (www.WB).

A quasi-symbiotic situation has been created. On the one hand, there is mass discontent and on the other, there is its misuse by the political parties in the conditions when in Albania there are no poor politicians. If in communism, almost the entire people were under the command of the Party of Labor, now in transition, the people are under the command of the two main political parties, the Socialist Party and the Democratic Party. There is also another relatively small mass of people linked with the smaller parties which are in the game as part of the coalitions. The general anthropological situation is this: A very rich minority and a poor and insecure majority of people, which has created a situation that Joseph E. Stiglitz calls "the price of inequality" fraught with all the consequences inherent in it (Stiglitz, 2012)

What is the Albanian society in transition like? It is merely a society of people in need. As Hannah Arendt said, "A society in need is a pre-political society not because it does not want to be such, but it cannot be." (Arendt, 2002). This is the reason the rule of law does not function in Albania and why the transition has created a climate of pessimism and distrust in institutional democracy.

\subsection{A formal system without mechanisms...}

\subsubsection{Democracy as a culture in plural is still insufficient in Albanian democracy, why ...?!}

At the onset of the '9o, it was propagated that in the former communist countries, "Democracy through the rule of law" would bring about a new institutional culture which had been lacking until then, a democracy that is called "checks and balances", meaning that the branches of power would be independent, cooperative, and supportive of one another, respecting constitutionalism, the law and the decision-making of the Constitutional Court. The expectation was to install mutual cooperative and unobtrusive checks among the institutions. Furthermore, it was expected to have a reality where the law would be an independent institutional entity that would ensure the equality of citizens before the law." What did happen in fact was "The use of law as a political weapon that distorts the idea of equality before the law." (Zakaria, 2006, p.93).

"Instead, the personal, clannish, quasi occult control of the branches of power has been established and their opposition which is often antagonistic." People were not educated with the principle of coexistence of "the political culture in plural" or as otherwise known "political cohabitation". Irrespective of what wing you belong as a political force, in the majority or minority, in representative democracy one has to accept that there is more than one alternative and that you can cohabit with it or them in diversity and competition within the institutions." In a democracy, political discourse aims not only at getting to know the reality (the cognitive function) but also at winning the election and holding the power (the manipulative function). Hence, the free political discourse does not necessarily yield more visionary policies than those of the authoritarian regime that suppresses the opposition." (Soros, 2012) ${ }^{6}$.

\footnotetext{
${ }_{5}^{5}$ Joseph Stiglitz, The Price of Inequality - How today's divided society endangers our future. "Not just in the United States but all around the world, there is mounting concern about the increase in inequality and about the lack of opportunity, and how these twin trends are changing our economies, our democratic politics, and our societies, 2012, p. 1 of the preface.

${ }^{6}$ George Soros. The function of manipulating the reality has become a global disease. "The theory of representative democracy implies that candidates introduce themselves and their programs and that the electorate elect the one they like best; it does not foresee that candidate study public opinion and then tell the electorate what they wish to hear" 2012, p.70.
} 
Institutionalization in the Albanian democratic reality did not create trust because elections, either local or legislative, have not resolved the problems that unfortunately have been rolled over from one decade to another. Much has been said over the years about the electoral codes, about changing and amending them, and about successes and failures in the election process. It is many years now that we have been hearing suggestions made by ODIHR and the OSCE about elections in Albania; but no matter whether they have been legislative or local elections, they have never been certified by specialized international institutions as "free and fair elections." Their results have been accepted with or without reservations, followed by suspicions, criticisms, and finally, by the boycott of the very institutions established by the elections. Worse still, we have witnessed trafficking in votes within the institutions, and swings of the elected members from one party alignment to another. Even the candidates voted by a qualified majority in parliament have in some cases been the byproduct of unprincipled compromises. Where the votes have been trafficked within parliament, members have been elected by made-up qualified parliamentary majorities thanks to changing circumstances or unprincipled interests played by cunning minorities. Even the President of the Republic (after the legal amendments) was elected with a third round of votes, with a simple parliamentary majority. Such a practice has harmed the system of "checks and balances." The separation of powers has been left up to changing circumstances, the interest of holding on to power, and of having almost absolute control over the branches of power. Institutional democracy has been reduced not to having a slice of the "cake", but to possess the "whole cake". That was the slogan that Mr. Edi Rama used during the last election of 2017.

What has happened? Collective representative democracy and the institutions springing from it did not ensure trust, therefore, the delegated sovereignties of electors failed to become the decisionmaking authority. The public interest was trampled underfoot. In this transition without any benchmarks, for which all the political parties in the political game are responsible, what happened was that political coexistence did not yet become a culture of tolerance, an institutional climate, and behavior, a need and mentality, in order to ensure the functioning of democracy. There have been two distinct approaches during the transition period.

The most common approach is the capture of all branches of powers by the parliamentary majority, even the independent constitutional institutions. The same political party that has the government also elects the President and supervises the appointments in the judiciary system and other "independent" institutions. Under these conditions, the parliamentary minority is treated as an appendix of the collective representative democracy. It has no power in decision-making, its alternatives or its voiced opposition is disregarded."...The governments that have emerged from elections have, under the allegation that they represent the people, always violated the power and the other elements of the society, a capture of power that is simultaneously horizontal (the other branches of the national government) and vertical (the regional and local authorities, and the private business, or other non-government groups, like the media (Zakaria, 2006, p.101).

We have passed from the totalitarian monocratic system into a double monocratic allegedly democratic system. (Authoritarianism alternated according to the political party in power).

This monocolor system with alternations (according to the election winner) has asphyxiated the "check and balance" mechanism. The branches of power do not check or balance one another concerning the constitution and the law. Everything is decided by the leader or the top leadership of the party in power and then the decisions are transmitted vertically in the form of orders, which are enforced without any opposition. Where in some of the higher state institutions like Parliament or the High State Audit, the Prosecutor General or the President of the Constitutional Court, and others - due to their mandates which may last longer than that of the political party that has elected or assigned them but which, being no longer in majority has in the meantime left power, - political coexistence in the institutional life that normally should be governed by the constitution and the law has not functioned as a regulatory mechanism. The political forces stick to their respective trenches. Exclusion and distrust are prevailing, and political conduct is that of mutual disregard. Dynamic cooperation is replaced with institutional antagonism and attacks against one another. Owen (2004) 
considers the value of a political system as depending on its effectiveness and on the balance that it can strike between progress and the overturning of established structures. He describes how it should happen, saying "a parliament is elected, while a government is appointed to ensure proper dynamic management of the country, and the balance in question is not easy to find." (Owen, 2004).

Such a philosophy is typical of feudal anthropology. Power or position is seen like the former fortresses, fees, or feuds that received orders from no one and rendered account to no one. Each branch of power, through overt or covert agreements, controls the state. In this situation, the parliamentary majority behaves arrogantly, reminding us of what Herbert Spencer said, namely that, "Even parliamentary majorities may be transformed into authoritarian majorities." (Spenser, 1844) 7 . Furthermore, in relation to the dangers of democracy, Alexis Tocqueville warned of two dangers: "the tyranny of the majority and Soft despotism" (Tockequeville, 1835).

So, democracy, too, both as a culture and as a system, is at risk of excesses. Tocqueville cites James Madison and Thomas Jefferson in their reasoning on this issue. For Tocqueville, the most effective restrictions of the possible tyranny of the majority in America are:

- Decentralized authority,

- Voluntary associations,

- Lawyers,

- Juries and the judicial system

Nevertheless, he admits that there are no guarantees that such a tyranny may be eliminated completely. A more hidden risk but still related to democratic freedom is "Soft despotism". According to Tocqueville, such a form of governance is born when people give up their independence and free will in favor of an ever more centralized and authoritarian government. Here Tocqueville sees the materialism and concern of Americans for their wellbeing as a danger to authentic democracy. Almost without realizing it, the citizens may surrender their free will to a "greater protection power ", provided that they remain affluent and comfortable." (Tocqueville, 1835).

Although Tocqueville's tenets were formulated a long time ago, they remain valid to the current situation Albania is going through. The Albanian transition immunity systems are not operational, instead of decentralization, there is centralism, if not by law, by orders. Instead of a conscientious, active, and depoliticized civil society, we have a captured, politicized society being servile to the executive branch in power for pecuniary purposes. Instead of an independent, trustworthy, professional, and honest system, in the last 30 years, we established a corrupt, politically captured system of justice, linked with organized crime.

"Soft despotism" is likewise present since all the government we have had during the transition have come to office under the oath of building a democratic, transparent, cooperative system, and very soon they were transformed into closed occult centers, accumulating in their hands all the decision-making powers, until they come to a point where the power controls the state. The other mistake is that citizens tend to run after their immediate material interests, thinking that if they delegate decision-making to the state bodies, the situation may change. All this is happening in the conditions when institutional care towards sovereignties, freedom, and democracy are missing, which

\footnotetext{
${ }^{7}$ In 1844, Spencer published four essays in the Contemporary Review which later were collected in his masterpiece work "Man Versus the State". In relation to our topic, of interest is the essay titled "The Great Political Superstition." It is a fact that the royal powers were built on superstitions, since the royal power was considered delegated from the God and royal blood as blue blood. There is also a ceremony that began in year 8oo, when Pope Leon II for the firsttime crowned Charlemagne Emperor. Oliver Cromwell sent the King to the guillotine and after smearing his hand with his blood, he addressed the people with the demystifying words: "You see, it is red, not blue". But the man who to some extent ignored this ceremony was Napoleon, who told the Pope: "I will have the crown". Spencer warned that even the legislative powers may end up in superstitions: "The great superstition of the past is the divine right of monarchs. The great current superstition is the divine right of parliaments. It seems as if this holy oil has flown unnoticed from a man's head (The One) to the heads of a multitude of individuals, giving them and their decrees divine power."
} 
are the main attributes of citizens as the subject of democracy; they establish precisely the relationship that Tocqueville warned of.

In our political reality, in so far as the arrogant political majorities do not reckon with independence or competencies of the institutions in general, and the constitutional institutions, like the President or the Constitutional Court, democracy is endangered, freedom becomes but a slogan and people's discontent find no obstacles to pour out in the street chaos. Such behavior by the President of the Republic is also disturbing, where instead of rising above the parties and implementing the Constitution and constitutionality, he ignores every decision taken by Parliament, returning them, or failing to decree some or most of the decisions of Parliament, sometimes finding fault with trifle matters without any serious motive, and sometimes expressing his opposition quite openly as a manifestation of his party position. Political conduct is governed by the antagonistic principle: "either with me or against me", "Either a friend in my trench or an enemy in my adversary's trench". It is indeed unimaginable how many political and institutional factors and actors fail to understand (or ignore) liberal democracy, failing to consider the important principle that, "freedom is in its essence linked with the institutions and their proper functioning, that freedom is a tangible reality where institutions coexist and dialog with and respect one another's independence, in order to create the legal mechanism of institutional synergies. Where the fundamental institutions of the state produce exclusion and antagonism and ignore the individual and his rights, it shows that democracy is at risk in this society and the traces of totalitarian behaviors are still quite present (Arendt, 2002 $)^{8}$.

\subsection{Personalization of institutions and personal authoritarianism...}

\subsubsection{Captured institutions and the personal power of their heads}

The experience of Albanian transition has almost always shown that when someone comes to the head of a ministry as the next minister, that person shall make two changes: 1-Restore the building of the ministry, he/she heads (meaning, allocates a large amount of money). 2- Amend the organic law governing the work of the institution with the only aim of enhancing his/her personal power and opportunities for profit-making. There is a philosophy of (un)institutional behavior of overpopulation with legal acts and bylaws, while at the same time avoiding policies of actions and reforms. In fact, even the structural changes at the level of ministries (mergers or separations) become unmotivated, merely to enhance the control of and possibilities for decision-making, becoming a right in the hands of very few people. Albanian scholar Ylli Çabiri, former minister and now a highly even internationally esteemed expert, in his study on transition in Albania, dwells at length with arguments and statistical data and graphs on this worrying reality. He states “.... The negative record was reached in 2012 when almost all the draft laws tabled by the Council of Ministers and approved by the Assembly and then decreed by the President of the Republic are merely amendments of former laws or laws on the adoption of international conventions and agreements. Such a thing unequivocally shows the lack of vision..., while we were waiting for decisions on reforms, the ministers did whatever came their way ....We have been systematically misled by the government speaking about hypothetical and ongoing reforms, where in reality, in the best-case scenario, the

\footnotetext{
${ }^{8}$ Hanna Arendt, The Origins of Totalitarianism: "The human being that has lost a place in the community, his political status in the efforts of his time and the legal personality that makes his actions and part of his destiny, one constant whole is bereft of those qualities that usually may be articulated only in the sphere of his private life and that need to remain un codified, simple existence in all the issues of public interest. Equality, unlike what is entailed in mere existence, is not given to us, but is a consequence of the human organization so far, while being guided by the principle of justice. We are not born equal; we become equal as members of a group through the power of our thoughts in order to guarantee ourselves mutual equal rights. Our political life is based on the supposition that we may generate equality through organization," publisher DIJA, Pristine, 2002, pp. 391, 92.
} 
ministers tried to learn the art of governing and did not carry out any reforms, or carried out reforms only in words, engaging only in politics, but without taking any decisions." (Çabiri 2018).

Such a climate of negating what was done hitherto by constantly amending the laws misguides the dependent institutions, entities, and individuals involved in this game. Suffice it to have a look at only one of them, the Law on Higher Education in the Republic of Albania, which aims at ensuring the real application of higher education in what has come to be known as the Bologna Process, the establishment of qualitative education and guaranteeing the mobility in the European area of higher education and beyond. During 10 years of 2007-2017, this law was amended three times. (Kabo, 2017) ${ }^{9}$.

The student protests at the end of December 2018 also targeted this law. It was clear that the students, the pedagogues, the political parties, and the commissioned media outlets lined up in the same trenches against the law on higher education. Nothing was said by them, and less so by the law, about the "Curriculum revolution", the new systems of teaching and scientific research which today are broadly experimented practices, as the case is, for example, with the trinomial sciencetechnology-technical innovation, or about education through corporations or what is known as the STEM system (science-technology-engineering-math). The law does not mention the millennium development goals even in the context of its objectives (Kabo, 2017) ${ }^{10}$.

Such an archaic mentality towards legality and institutionalism has caused great damage that needs to be addressed. Experts are unclear and unsure about what they say and suggest, being under the constant pressure of losing not only their jobs but worse still, even their status, so necessary in decision-making. Technocrats feel misused in the expertise they provide, ignored in the drafting of strategies, and as primary factors in the formulation of policies of change and the relevant action plans. No attention has been paid to what UNESCO experts have suggested: "Over the last decades, schools have had to change their role from reproducing subjects accurately to fostering the growth and development of student's critical thinking and digital competencies for participation in the society and economy of Albania and beyond." (UNESCO, 2017).

Instead of science-technology-innovation and career technocrats leading the decision-making process, the opposite is happening. It is politics, partisanship, mediocre and (mis)used militants, the commissioned media outlets, and the street protests that determine the direction of change, the institutional policies, and the duration of laws. History begins with those who come to power or in leadership, and who are guided by the mentality of "it is I/we who know how things are done", and "those who were here before me, have gotten it wrong". And worst of all is that even the technocrat experts are divided along partisan lines as if science is not one, but two, as if the constitution is not one, but two, and so on, as if European integration is not one but two, and the country's development is not one but two different things. Unfortunately, we have built the sinister culture of discontinued

\footnotetext{
${ }^{9}$ Përparim Kabo, "It should be made known what is the basis of the legal amendment that is recently proposed and if it is consistent with previous laws, because the law is not just a juridical matter, but also an institutional one. In any case, the progress of a work practice is an expression of the history of the legislation in force, which for better or for worse had until then been functioning, therefore it cannot be ignored. Since we are talking about higher education, the law should at all times take account also of the previous law on pre-university education and everything related to the continuous education of different age-groups, from the preschoolers to the post- university students. Where changes result in partial operations, no matter how positive they may be, they are not valid because they destroy the 'conveyer belt', resulting in the clash of opposite wings and the individuals who go through all the educational cycles may have to be subjected to different philosophies or, worse still, their path to education may now and again be fraught with many obstacles, because the laws of the same state on education are unable to interact, understand one another and create a climate of legal and institutional synergies, "Kuvendi" review no. 7/2017, p. 48

${ }^{10}$ Përparim Kabo- The impasse of the Higher Education in the Republic of Albania and the (il)legal confusion become clear if we compare the principles and the objectives of the law with the universal principles of development of higher education in the $19^{\text {th }}$ century. Let us refer to this document: "Trends in Global Higher Education: Tracking an Academic Revolution, a report prepared for the UNESCO 2009 World Conference on Higher Education." "Kuvendi" review, no. 7, 2017, pp. 51-56.
} 
and captured institutionalism that, no sooner out of the claws of the outgoing political party, is recaptured by the incoming party in the country's leadership and governance.

We lack the criterion propounded by Max Weber that in the administrations it is necessary to have a sustainable anthropological mass of "career managers, politicians who pass through the path of managers and the Erudite. Our institutions frightfully assume the face of and identify with their leaders, who entirely ignore tradition, institutional continuity, work in process, current obligations, and contractual legal rules and liabilities." The current aspects of authoritarianism, considerably present in our institutions are linked with very essential elements like:

- The low cultural level of the leading individuals,

- Marked conceptual and decision-making weaknesses, not in line with the legal requirements and progressive technological developments,

- The rural and provincial origin of the leaders that keeps them hostages of regionalism, nepotism and impose on them tribal-like forms of behaviors,

- The doubtful education and scientific qualification of the leading staffs of the decisionmaking units,

- Rising above the institutions.

- An anthropological typology of deformed characters who quite openly use individual authoritarianism, and revengeful and denigrating attitudes towards brave individuals who are more cultured and progressive than them,

- Individual authoritarianism emerges where professional competence is missing and the person in leadership has an inconspicuous, incredible, or even worse public persona, compromised in the eyes of the public and his/her associates,

- Personal authoritarianism is the feature of individuals who are unable to meet the challenges of development and cannot keep up with the pace of progress,

- Authoritarianism characterizes corrupt leaders whose style of work is characterized by dictate, pressure, and authority.

\subsubsection{Relation of the leader with the institution...Anthropology and institutionalism...}

Personalization of institutions and personal authoritarianism is characterizing Albania's very long transition. The leader has unrestricted freedom to exercise his/her broadest authority based on the laws that they themselves amend, but also through the use of the verbal order instrument, which obliges the institution and teams to implement the orders even when they are more than the law, do not comply with the rules in force, or run counter to the fundamental institutional statutes. At the same time, the same authority in power stifles others' freedom, which is not respected and exercised, although recognized by their civil status and based on the law as a link in the institutional processes. The mechanism in all its gears of institutional hierarchy is invalidated regularly, avoiding legal powers, divested of freedom based on legal norms, defunctionalized by the exercise of responsibilities that should be recognized as a right in all levels of leadership. There is only one scheme of operation: "The head (his/her order) on the one hand and frightened nullities that need to enforce the orders, on the other."

Such a form of institutional ownership is protected against criticisms using propaganda. The attacks and insinuations made (not every critical remark is just, nevertheless what is said about the institutions needs to be grounded on arguments), the attacks against abusive leading individuals get mixed up deliberately with attacks against the institutions. (Read: if you attack me, you have attacked the institution). Individual failure is sold by authorized officials as inherited institutional weaknesses. Such kinds of officials try to unify their weak personal, civic, cultural, scientific, or institutional consciousness with the institutional consciousness of the team; and by so doing, they also make some minor sacrifices. Finally, they sell the dismissal of such people from their posts as a plot of politics against them, as a loss for the institution short of leading to "fatal circumstances of national catastrophe." The other side of the medal in the general atmosphere of Albanian institutionalism is 
personal authoritarianism. It is manifested in the form of open disregard for legal attributes, institutional life, and rules, dictate through personal authority, depersonalization of associates, and placing them under their control." (Kabo, 2006, p.223)

There is a discrepancy between appearances and the real situation. "Albanian society continues to be held ransom by personalized institutions misused by subjective personal authoritarianism. ...On the surface of it... one may create illusions about the legal system and the rules of the state that seem to be functioning. In fact, their failure to function....accounts for the ordinary men and the mass of not highly cultured people resorting to the behaviors and mentality of feudal anthropology. Even after 30 years of transition, there is more talk of democracy than it analyzes what it is and how it works. Today, the term "democracy" is often, and incorrectly, used as a synonym and at times, equally incorrectly, as an antonym for constitutionalism, liberalism, or republicanism, says Marian (2014), citing Josiah Ober. Marian highlights the Ober aim to "get clear about what we mean when we use the term 'democracy."' Misunderstanding what democracy is, Ober warned, can have tragic results. "After struggling through a pro-democratic revolution or some other difficult process of regime change, there will be a great deal of frustration and anger when [people] come to find they don't yet have what they thought they wanted... Democracy is today challenged by populism and elitism and by the resurgence of new forms of authoritarianism. The Spirit of Democracy: Corruption, Disintegration, Renewal shows that while we have good reasons to worry about the corruption of democratic practices and ideals, these worries are often attributable to questionable assumptions about what democracy is (Marian, 2014).

This mentality is demonstrated through praises lavished at the "brave" (cult of the savior), the creation of utopist daydreaming relations (for the unfortunate), and the establishment of real business links, through profit-making and favoritism (for the lucky ones), that help establish direct links with the individual- the heads of the state institution, the legislators, the decision-makers, the financiers, the administrative leaders or the local authorities." (Kabo, 2006) ${ }^{11}$.

The other side of the medal is the restoration of the ministry buildings at soaring costs which every new minister who comes to office does or that results from the reshuffling of the ministries. It is therefore necessary to conduct a specialized audit and come up with general estimates of such costs. The figures that the State Audit Commission (KLSh) publishes now and again about expenses incurred by the central departments show that they are very inflated and unmotivated, almost hedonistic for a poor state. The report of the State Audit Commission for 2017 in its item "Reorganization of Ministries, "says: "The process of reshuffling has brought about changes to the Ministry of Finance and Economy, the Ministry of Health and Social Welfare, the Ministry of Tourism and Environment, the Ministry of Infrastructure and Energy, the Ministry for Europe and Foreign Affairs. From the audits conducted by the KLSh, it can be noted that the consolidation of financial statements and the budget process has been carried out only by the Ministry of Infrastructure and Energy, which was formed by the merger of the former Ministry of Energy and Industry, the former Ministry of Urban Development and the Ministry of Transport and Infrastructure, and the Ministry of Tourism and Environment (KLSH Report, 2017) ${ }^{12}$.

\footnotetext{
${ }^{11}$ For more detailed information on the same study titled: "Authoritarianism in Transition"- Albanian Anthropology through Globalisms, first edition, October 2006. In this book, you may find also such exhaustive arguments as, "The State as Anthropo-Moral Curator of Society," "Globalization to Open a Closed Mind," "Democracy between Desire and Reality" "Wounded Democracy," "Snob Politics and Albanians' Plight, "Personalization of Institutions and Personal Authoritarianism."

${ }^{12}$ Fragments from KLSh Report, "The Ministry of Finance and Economy which took over part of the former Ministry of Economic Development, Tourism, Trade and Entrepreneurship (MZHETTS) and part of the former Ministry of Social Wellbeing and Youth (MMS) did not carry out the consolidation process both in terms of financial position and performance. Although the former MZHETTS staff had drafted the list of assets, it was not consolidated and accounted the financial statements of the MFE apparatus for 2017, worth some ALL300 million. The same act made it mandatory to consolidate the assets of the former MMSR according to its areas of responsibilities, which it had been granted under specific programs, but which turns out not to have been implemented due to lack of cooperation by the representative of the former MMSR (in MSHMS) with the group assigned to execute the order. www.klsh.org.al
} 
The expenses for the qualification and specialization of the central departments and lower levels staff are not the main budget expense item. No priority investments are made for training the human resources and for building intellectual and technocratic capacities. There is no national strategy for the creation of technocratic elites, which may be sent abroad for more profound studies to establish the class of Eurocrats and globalocrats. The new technologies, both digital and artificial intelligence, are not part of the guided development of our country. Of course, the necessary organization, management, and decision-making that accompany such a new social, political, and institutional culture are missing. We continue to witness hesitation, lawlessness, doubts, and disregard for progressive change, typical of an oriental mentality inherited from the time of the Turkish-Ottoman occupation. Often for populist purposes, some people are dismissed from work and some others are collectively recruited, as the case was recently when Mr. Edi Rama ordered, based on a government decree, that excellent students be employed in central government departments, infringing thus all the rules set for the recruitment of the staff in the civil administration.

As Henry Kissinger says, "The basis of a pluralistic society is consensus about fundamental values that clearly define the boundaries of the claims of individuals or rival groups" (Kisinger, 1994, p.665).

But are there in our society fundamental political values based on which people can work to find consensus? Unfortunately, there are not! Lack of national strategies that are accepted by all and are coordinated with the political parties as strong foundations for development, clearly shows that in our reality exclusion continues to prevail. The fundamental value should have been "Democracy through the law," but we failed to implement it and there is still a very long way to go; although it is almost three decades that we are in transition. The law was traded in the market for as long as the courts became corrupt and today are undergoing a vetting process under international monitoring. Democracy was also traded in the market in so far as freedom is being exchanged for material effects, and instead of functional democracy, policymaking is offering the citizens material effects. Democracy through the law was heavily shaken in so far as in parliament the people were represented by criminals, and it was necessary to draft a law to decriminalize it. As the former European Commissioner Chris Patten (2015) has underlined: "Too often in Brussels, we pretend to believe the promises that were made by Balkan governments about law enforcement, corruption, and organized crime, when in fact we and they knew that the promises were like a piecrust."

The value of a pluralistic society lies in a political culture in plural and political coexistence, but this too was not properly done in our very long transition. In our political, institutional, and civil society and community life, hatred and exclusion are still present. A consensual value in a liberal democratic society is the care that should be taken for the state not to be dehumanized and abandon the public interest (or even worse to sell or replace it with the private interest). But this too is nonexistent in Albanian society. The corridors of politics have been occupied by the market oligarchs. They are the ones that order lawmaking. The fundamental values should have been general development, prosperity, and quality economic changes that can bring about the wellbeing of all the strata of the society in order to guarantee a welfare society. Easterly (2007) analyzing the role of inequality in the (under) development mentions that "Countries with high inequality tend to invest less in public goods, such as infrastructure, technology, and education, which contribute to long-term economic prosperity and growth. Reducing inequality, on the other hand, has clear economic as well as social benefits. It strengthens people's sense that society is fair; improves social cohesion and mobility, making it more likely that more citizens live up to their potential; and broadens support for growth initiatives. Policies that aim for growth but ignore inequality be self-defeating, whereas policies that decrease inequality by, for example, boosting employment and education have beneficial effects on the human capital that modern economies increasingly need."

In fact, we have a society in need, that is, a para-political society. Values determine the boundaries of individuals, who are different but have things in common; and still, during the years of democracy, we could not build the institution of the individual.

The individual was not provided what Anthony Giddens says, “...the possibility for self-change.” The man was left so to say in the street, or to become an ordered "pion", or was left seated on the 
chair to take selfies on the orders of the leader. Values also determine the boundaries of rival groups but here with us, instead of rivalries with political alternatives, there is antagonism, which feeds also on historical roots from the former systems and times. Although it is three decades now that communism was overthrown, in our minds we have not yet outgrown it. As a society, we are a social group without any interest in the values uniting us. Disoriented, we merely toe the line of the "muezzin"13 from the political party temple. Are we therefore a society of European values? This question needs to be modified. How much time do we need to become such...??? A long time, unfortunately, a very very long time...!!!

\subsubsection{Misunderstanding with and about property}

The long transition is the byproduct of the situation created as a result of the misunderstanding of freedom but also as a result of the approach to property. We do not yet have a clear concept of the terms, "freemarket initiative," "the visa-free movement" and "freedom in a liberal democratic society." Anarchy regarding the issue of property is the worst one. Internal mobility has been coupled with usurpation and capture of public and private properties. Such conduct which violated one of the three fundamental freedoms, as John Lock defines it (freedom of life, freedom of property, and freedom of expression) was transformed into a collective pathology that has spread almost across the country's territory. From the Old Gospel, the property was considered 9/10 law and 1/10 asset. Such a juridical and moral meaning was not valid for the Albanian society in democracy. Destruction of national assets, public and individual properties have caused damages not merely to the assets but also to relationships because:

- Denaturalization of national wealth, its transfer from the people to the privates, who either grabbed it or it was given to them by political decision-making, on the condition that profit is divided, resulted in a minority of people getting extraordinary rich and the majority of the people remaining poor.

- Alienation of public assets has led to their reduction and to their survival being conditioned by private management, with the public decision-making institutions playing the role of the go-between and to the creation of a climate where it is believed that public interest is not the main obligation of the state.

- Willingly or unwillingly, it was created a populist anarchy for the plunder of public spaces and most of the private properties, fostering thus collective informality, a reality that overthrew the rule of law and established a compromise between the state brought to its knees and informality, which enjoys the respect of the state thanks to the legitimization of the illegitimate....

When the situation became alarming, the state launched the legalization process, taking the case of informality first and then, where it could, of the legitimate owners. Making laws and bylaws that help those who steal others' properties or public properties legalize their stolen properties and to be unable to find a legal remedy for the legitimate owners to enjoy their inherited properties, means the state accepts informality and institutionalization of anarchy and plunder. (ALUIZNI, 2014)

In such circumstances for the Albanian transition is hard to find a correct answer about what shall happen with the citizen's sovereignty. Is it the individual, the citizen, the voter, or the community that is endowed with the primary right of exercising delegated power, or those that after taking such sovereignty by virtue of the vote, forget that they are there to serve and not to lead; or worse still, not to give commands? In communism, this right was trampled underfoot through collectivized conscience. In democracy, it is being misused due to privatized conscience. Several generations have experienced disillusionment from their state and the branches of power. The state has surrendered to informality on the one hand and the interests of the oligarchs on the other. Such a

\footnotetext{
${ }^{13}$ Muezzin is the person who calls people to pray from the minaret of a mosque.
} 
situation has created disillusionment and undermined the agreement of trust between the citizens and the powers elected with their votes.

"Every power is given on trust that it is going to achieve a certain objective and that it shall be restricted by that objective." John Locke states (Locke, 200o, p.176). He further points out: "Where we openly ignore or contradict such an objective, trust is certainly lost, and power is returned to the hands of the voters that gave it away and who can give it away again when they think that this is best for their own security and wellbeing. Thus, the community always holds the supreme power to withstand the temptations and oppose the aims of whoever it may be, even their own legislators when they are so crazy or sinister as to draw up and implement plans against the freedom and properties of the citizens."

Unfortunately, this is how far democracy has gone in Albania. Freedom and property are not respected. In order to cover up such a situation, populism is being fostered in two possible ways. Populism in the streets and populism in the meetings held in halls, or institutional populism. Crowds taking to the streets are a manifestation of ochlocracy, while the crowds of organized meetings pose as alleged law-abiding citizens. The formers are those who protest and commit violations and the latter who keep silent and listen to their leader. How does such a mechanism operate in the transition Albania? While in the communist-type populism of the past, they used to speak about the legendary leader and the working masses, about the unmistakable Marxist-Leninist and the heroic people, now they speak about the anti-corruption crowds and the political leader in office. In the totalitarian system, meeting halls were filled with ideologically modified people who, as if by a magic wand, burst out in applause and ovations, in shouts and best wishes for the leader, glorifying his figure. Even now, in the transition period, in closed halls or the open air, militants or public servants working in the administration seem to listen in awe to the leader, burst out in constrained laughs at his repartees, put up with all sorts of prattle and burst out in ovations, and even call their leader a modern national hero, the Scanderbeg of our time ${ }^{14}$. How does such a mechanism operate? Let us have a closer look at it.

Institutional populism has been used by all the political wings in Albania. The way how it works is more or less like this. The need for change is initially propagated as an anthropological demand and pressure coming from the bottom up, from the people, from those who are worried, from the interested community. Then, as a pressure exerted by the whole society. This situation is played up in the media through publications, interviews, meetings, at some alleged roundtables of talks, seminars, or conferences, sowing thus the seed. Further down the road, the project is forgotten, some hazy words are said about the identified policies of actions, and quickly "the working group" is set up, the "ordered workers" who draft the reform. The second act is allegedly linked with the interest groups. The parties are engaged in an incredible game. Those who are invited to voice their opinions, do not even look at the written materials, or cast a bird's eye view of them and pretend to come up with some criticisms. Then the "passe-partout"15 persons are found who give panegyric speeches in support of the reform and point out the leadership's farsightedness, throw some fireworks against the government, feign hypocritical surprise at the expected "revolution" and finally, pour the last drop of energy, saying, "Thank God this day came, and we are realizing the overthrow we could hardly wait to see.”

Nothing concrete comes out of such meetings. Everything is being instrumentalized in the conformist scheme that leadership knows everything. There is no reference model. No questions are asked about other models. What are the objectives and how do they compare with the universal

\footnotetext{
${ }^{14}$ George Castrioti Scanderbeg (6 May 1405-17 January 1468), our national hero, a medieval prince who fought against the Ottoman Turks in defense of Christianity and who was proclaimed by the Pope as the Captain General of the Holy See. The Democratic Party supporters have called Sali Berisha Scanderbeg, the Socialist Party supporters too have called Edi Rama as their own Scanderbeg.

${ }^{15}$ Passe-partout-comes from French, meaning a master key that can open all doors.
} 
principles of development? How can the budget be raised, and human resources have a higher level of qualification? How can the opinions of outstanding experts be drawn, and coexistence ensured in a multitude of alternatives? What are the expected potential scenarios of development? Nobody bothers to deal with such things. Some meetings are held with a large presence of audiovisual media outlets, some television talk shows at the peak hours, and then, they pass on to meetings organized in large halls where obedient crowds gather just to listen and not speak or ask questions, simply to keep silent and accept everything being said to them. The only thing they do not forget to do is to clap their hands.

In parliamentary commissions where draft laws are debated, nothing is taken seriously, some mots are exchanged, the parties take their respective political stands, some experts pretend to speak and then one of the party wings leaves the room and the remaining wing votes, the draft is submitted to the plenary debate and approved by parliament without any debate, without reading it at all, or misinterpreting it. There is more propaganda than real discussions. The political wing that is against it, declares that when it is coming to power, it shall repeal that law. Such a situation is reflected in some forms of hesitation in society. Where the law is expected to be implemented, there is hesitation. Do people ask whether they need to implement that legal amendment?! Will it withstand the time or after the other party comes to power, everything will be overturned, and we shall have a new law?! The other populist approach is that of street protest. When the Democratic Party wanted to oppose the law on Higher Education, this is what it did. It got together some students in the street, students who are members of the opposition party youth forum. They were instigated to attack the authorities, to pelt the prime minister with eggs, and to throw tomato sauce to the dyed hairs of the minister of education.

Some pedagogues inspired by their lack of reason dance to the revolutionization of the streets and squares instead of taking part in professional roundtables of experts. This is how a cause is built. Then the street crowds are joined by the opposition emissaries, the "competent" deputies of this field. They are joined also by the media outlets that have no work and no principles and whose owners have a stake only in the market and who are devoid of any public interest and the play ends with some television talk show. Neither the host of the show nor the guests in the studio have read the draft laws or by now the newly adopted law. With their hands in their pockets and with "powder" in their mind, they only speak ill of and stand up against the law. To make the show a semblance of a debate, they invite representatives from both the political wings who start hurling endless insults at each other. They may also find some naïve or cunning foreigners, whom they pay to speak against the draft law. Meanwhile, the crowd remains in the streets and continues its protests even when the law approved by parliament is sent to the Constitutional Court which proclaims it in compliance with the Constitution of the Republic of Albania.

At first sight, it appears as if institutional populism triumphs over street populism, but in the meantime, the law has not been read or studied by either party. Those who keep their eyes wide shut should enforce it, those of the street protests who have their eyes open neither wish to nor should they read it. Human reality is likewise split and divided. One horde of people is with the left, the other horde with the army of the right. One mass of people in the forum of one party, the other in the forum of the opposing party, like soldiers pitted against each other on a battlefield. Even those who are elected to nonparty forums, where they are required to be politically neutral, objective, and with integrity, openly side with one, or the other party. They can under no circumstances be independent and free. This kind of freedom is still a sacrilege in the reality of Albanian democracy. The only freedom-anarchy that functions is that of the party in power having docile soldiers of instrumentalized institutional populism. In the meantime, the other party wing is on the streets. Next time they change places, those of the street enter into halls, the others flood the protests like an indignant crowd that demands the lacking justice. This is misused energy, lost time misunderstood, and trampled underfoot democracy. This is why transition in Albania is a closed cycle that recycles the same people, the same mentality, and the same problems. As Erich Fromm said, the people who do not look towards the future, and deal only with the past, are afraid of Freedom! 


\section{Conclusion}

The conclusions of this study point out that:

- The basic principles of liberal democracy are either not sufficiently known or even where known, not properly respected.

- The political classes in Albania have during the entire transition not been inclined to implement their constitutional and legal obligations based on the principles of freedom, democracy, and the rule of law, on the contrary, they have been characterized by the capture of power and its branches. The party and state leaders have demonstrated a feudal type of mentality that treats society according to the scheme of "the crowd and the prince".

- Representative democracy is not duly based on the principles of institutional democracy.

- Human rights and freedoms are not duly and sufficiently respected. The trust agreement does not function because freedom of life, freedom of property, and freedom of expression have been affected.

- Democracy is missing as a culture of behavior and as a relationship between the individual and the institutions.

- In the Albanian transition society, the immunity systems are either lacking or not functioning properly. In many aspects, democracy is outside the control of institutions and the law.

\section{References}

Appiah, K. A. (2006). "Cosmopolitanism"- Ethics in a world of strangers".

Arendt, H. (2002). "The origins of totalitarianism" published by DIJA, Pristina.

Balladur, E. (2007). "Machiavel en Democratie", Published in Albanian language by UEGEN.

Camus, A. (2017). "The Rebel" Albanian edition.

Çabiri, Y. (2018). "Albania can be made" Onufri publisher, Tirana.

Domenach, Jean-Marie (1984). "Enquête sur les idées contemporaines", France.

Easterly, W. (2007). "Inequality does cause Underdevelopment".

Fallmerayer, J. P. (1850). "History of Morea in the Middle Ages".

Greenspan, A. (2010). "The Age of Turbulence". Penguin Books.

Kabo, P. (2006). "Authoritarianism in Transition," Albanian Anthropology through Globalism, 1-st publication, October 2006, Tirana.

Kabo, Përparim. Review “Kuvendi”, No. 7/2017, Tirana.

Kissinger, H. (1994). "Diplomacy".

KLSh Report 2017, www.klsh.org.al

Lipset, S. M. (1959). "Some Social Requisites of Democracy: Economic Development and Political Legitimacy", The American Political Science Review, Vol. 53, No. 1 (March 1959), pp. 69-105, Published by: American Political Science Association.

Locke, J. (200o). 'The Second Treaty on Governance” Publisher Dita, Tirana.

Marian, V. (2014). "Democracy meaning Ober", Stanford University, 2014 (retrieved by news.stanford.edu/news/ 2014/october/democracy-meaning-ober-102314.html)

Owen, B. (2004). "Good Governance: Establishing a Party System in Countries Undergoing Democratic Change", Elections Comparative Study Centre, Paris Universit.

Patten, C. (2016). "What next? Surviving the twenty-first century".

Soros, G.. The Soros Lectures: At the Central European University, 2010. IIS Publication (Institute of International Studies).

Spencer, H. (1844). "Man versus the State".

Stiglitz, J. E. (2012). "The Price of Inequality-How today's divided society endangers our future".

Stiglitz, J. E. (2015). "The Great Divide".

Tocqueville, A. (1835). "Democracy in America".

UNESCO (2017), Albania - Education policy review: issues and recommendations

World Bank, (2021). Macro Poverty Outlook for Europe and Central Asia. https://thedocs.worldbank.org/en/doc/ d5f32ef28464do1f195827b7eo20aze8-0500022021/related/mpo-alb.pdf 
Weber, M. (1906). "Zur Lage der burgerlichen Demokratie in Russland," Archiv fur Sozialwissenschaft und Sozialpolitik, Vol. 22.

Zakaria, F. (2006). "The Future of Freedom"- Illiberal Democracy at Home and Abroad, Albanian edition, publisher Institute of Dialogue and Communication. http://www.aluizni.gov.al/blog/2014/o6/27/hyn-nefuqi-ligji-i-ri-per-per-legalizimin-urbanizimin-dhe-integrimin-e-ndertimeve-pa-leje-te-ndryshuar/ 